\title{
Effect of common bean (Phaseolus vulgaris L.) seed viability on drying dynamics
}

\author{
Krzysztof Ratajczak, Roman Holubowicz \\ University of Life Sciences in Poznan \\ Faculty of Horticulture \\ Department of Horticultural Seed Science and Technology \\ Baranowo, 62-081 Przeźmierowo, Poland \\ e-mail: kxrx@wp.pl
}

Key words: seed germination, seed quality, seed ageing, seed testing

\begin{abstract}
'Tina' and 'Libra' cultivar seeds of the common bean (Phaseolus vulgaris L.) beginning germination capacity of $98 \%$, were subjected to artificial ageing. In the thermal chamber, they were twice treated for 72 hours at $45^{\circ} \mathrm{C}$. After the treatment, the seeds had lower viability. They germinated at $12 \%$ and $0 \%$ for 'Libra' and 'Tina' cultivars, respectively. The dynamics and rate of seed drying were measured in samples with high and low viability. It was found that the seeds of both cultivars with high viability, expressed by high germination capacity, dried at a slower rate than ones with low viability. In the future, this method of estimating the drying rate could probably be used to test seeds with different degrees of viability.
\end{abstract}




\section{INTRODUCTION}

Knowledge about a seed's viability could be used in practice to predict field emergences. For the same reason, weight of 1000 seeds and seed germination in low air pressure could be used (Artola and Carrillo-Castaneda 2004), as well as colour reactions of live or dead seed tissues (Kwong et al. 2005) or conductivity tests (Tarzali et al. 2005, Mirdad et al. 2006). Another group of methods to measure seed viability is based on certain chemical compounds such as lipids, specific lipo-oxygenases (Freitas et al. 2006) or enzyme activity (Fornal and Filipowicz 2007). A separate group of methods to measure seed viability are nondestructive methods such as x-ray evaluation (Mussumeci et al. 1994) or ultra red light spectroscopy (Tigabu and Oden 2004).

On the other hand, various susceptibilities of seeds to desiccation can be a useful tool to improve their quality (Modi 2005). Physical damage of seeds had been proven to affect their quality (Strona 1977, Chodulska and Polanka 2001). Loss of seed viability and vigour are connected with cell membranes' destruction, enzyme inactivation and genotype damage (Zalewski et al. 1997, McDonald 1998).

The main purpose of this experiment was to prove that seeds' drying dynamics could be a useful tool to evaluate their viability.

\section{MATERIAL AND METHODS}

The seeds of two snap common bean (Phaseolus vulgaris L.) cultivars, 'Libra' and 'Tina', were used in the experiment. They both are used in commercial horticulture, have green and yellow pods, respectively, and came from the Polish seed company "Torseed, S.A.". The seeds of both cultivars germinated at $98 \%$ (in filter paper rolls) in the laboratory measured according to routine germination rules (ISTA, 2004) and, to confirm, in sand at 97\% and 93\% for 'Libra' and 'Tina' cultivars, respectively (Fig. 1). Half of the seeds were then subjected to artificial ageing (Mirdad et al. 2006) at $45^{\circ} \mathrm{C}$ in a LAB-LINE L-C Oven thermal chamber, twice for 72 hours. At the first stage the RH was high due to open vessels with water put into the chamber, then the seeds were brought back to room temperature. After the first stage the seeds of the 'Libra' and 'Tina' cultivars germinated at $96 \%$ and $92 \%$, respectively. Then, just before the second exposure at $45^{\circ} \mathrm{C}$ in the thermal chamber, the seeds were placed into water for 30 minutes to increase their moisture content. The exposed seeds lowered their germination to $12 \%$ and $0 \%$ for 'Libra' and 'Tina' cultivars, respectively. The same seeds germinated in sand at $20 \%$ and $0 \%$ for 'Libra' and 'Tina' cultivars, respectively (Fig. 1). 


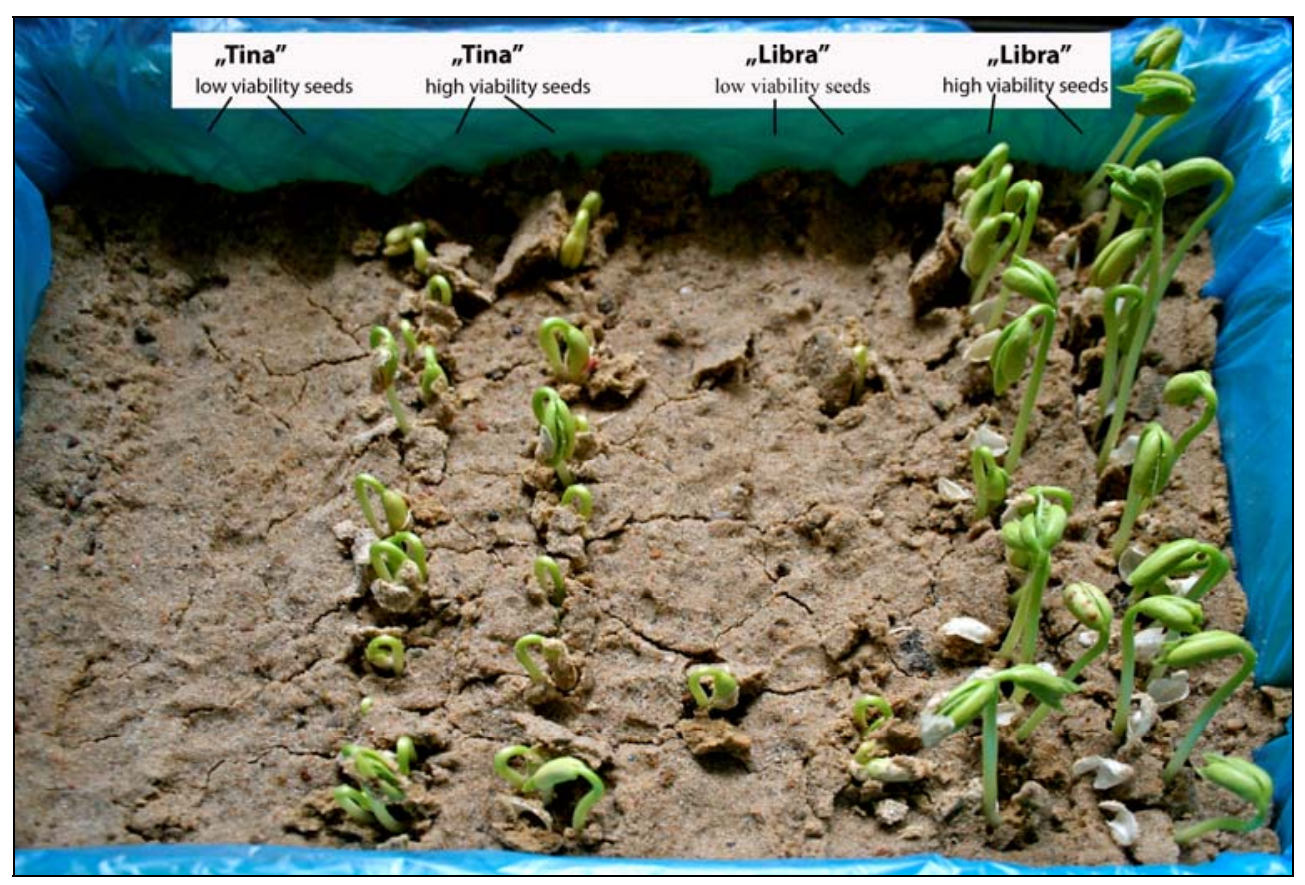

Fig. 1. Germination test for low and high viability seeds of two snap common bean (Phaseolus vulgaris L.) cultivars, 'Libra' and 'Tina', used in the experiment

For the treated (low viability) and non-treated (high viability) seeds, the drying dynamics (changes of seed moisture content) and the drying rate were estimated. The dynamics of seed drying was measured using the weight method. Samples of 50 air-dried seeds (seed moisture content: $7.5 \%$ for 'Libra' and $6.8 \%$ for 'Tina') were placed in filter paper rolls and put into water, where they were imbibed for 30 hours at $23^{\circ} \mathrm{C} \pm 2{ }^{\circ} \mathrm{C}$. The imbibed seeds were then placed in a Petri dish and placed on a "Sartorius Ba110S" scale interfaced with a computer using the "Sartorius SartoConnect for Windows" program to record their weight every 6 minutes. The test was done for each cultivar and germination group in two replications. The drying rate was calculated and expressed as changes of seed weight per a unit of time (g per $6 \mathrm{~min}$.). The significant differences in the figures were expressed as standard errors (SE).

\section{RESULTS AND DISCUSSION}

The carried out research proved that there were clear differences in drying dynamics and rates between seed samples with low and high viability (Figs 2-5). 
For the seeds of the 'Libra' cultivar, the moisture of the seeds with high viability declined more slowly than that of the ones with low viability. However, significant differences were only proven after over 19 hours (Fig. 2).

The drying dynamics of the second cultivar, 'Tina', were more predictable: low viability seeds lowered their seed moisture content more rapidly than high viability seeds. Significant differences were recorded already after 7 hours (Fig. 3).

The calculations of the drying rates proved that low viability seeds of both cultivars had higher rates than high viability ones. The differences were at first high, then decreased. They stayed significant for over 1 hour of drying for the 'Libra' cultivar (Fig. 4) and about 1 hour for the 'Tina' cultivar (Fig. 5), and then were significant again after 30 hours and 26 hours, respectively (Figs 4 and 5).

The results proved that analyses of the drying dynamics and drying rate could be a tool to evaluate differences in viability of bean seeds. Due to the fact that the seeds were analysed with the use of scales and computers, the proposed method is quick and cheap. However, it also needs further testing on both seeds of different species and bigger seed lots. The observed result of high viability bean seeds dehydrating slower than low viability ones was due to the damage to their cellular membranes. This is in agreement with the earlier findings of Zalewski et al. (1997) and McDonald (1998). It is also in agreement with the earlier findings that the conductivity test, based on changes of physical properties of cell membranes, can be a quick method to evaluate ornamental plant seeds' vigour (Hohubowicz et al. 2001).

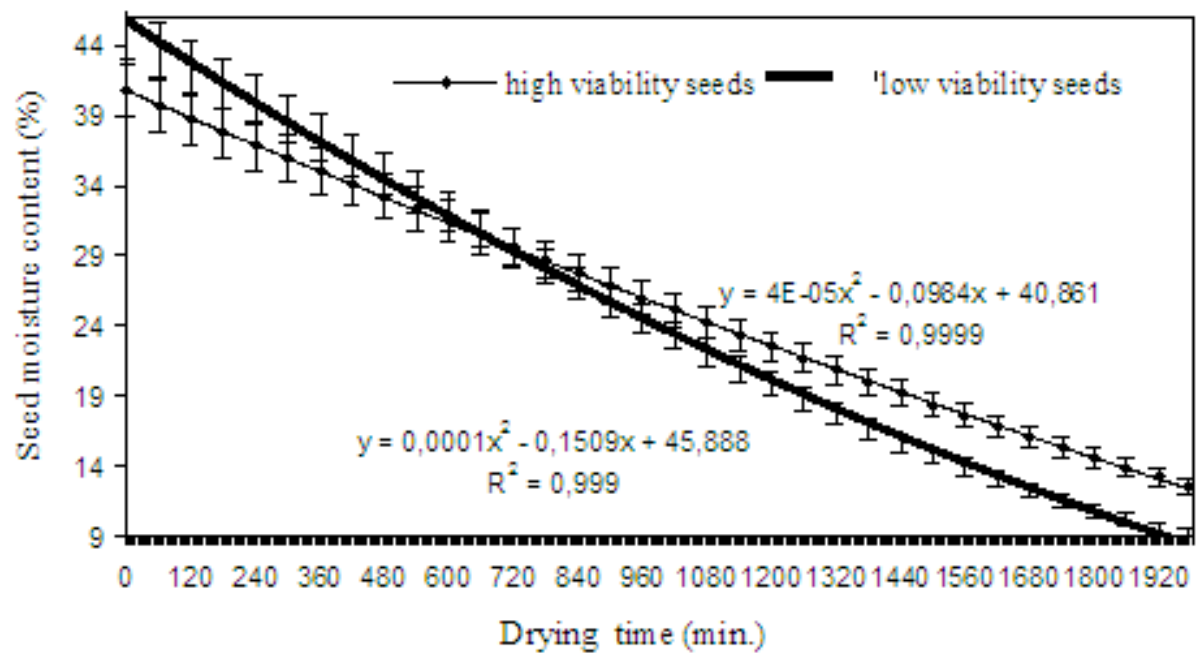

Fig. 2. Drying dynamics of 'Libra' common bean seeds 


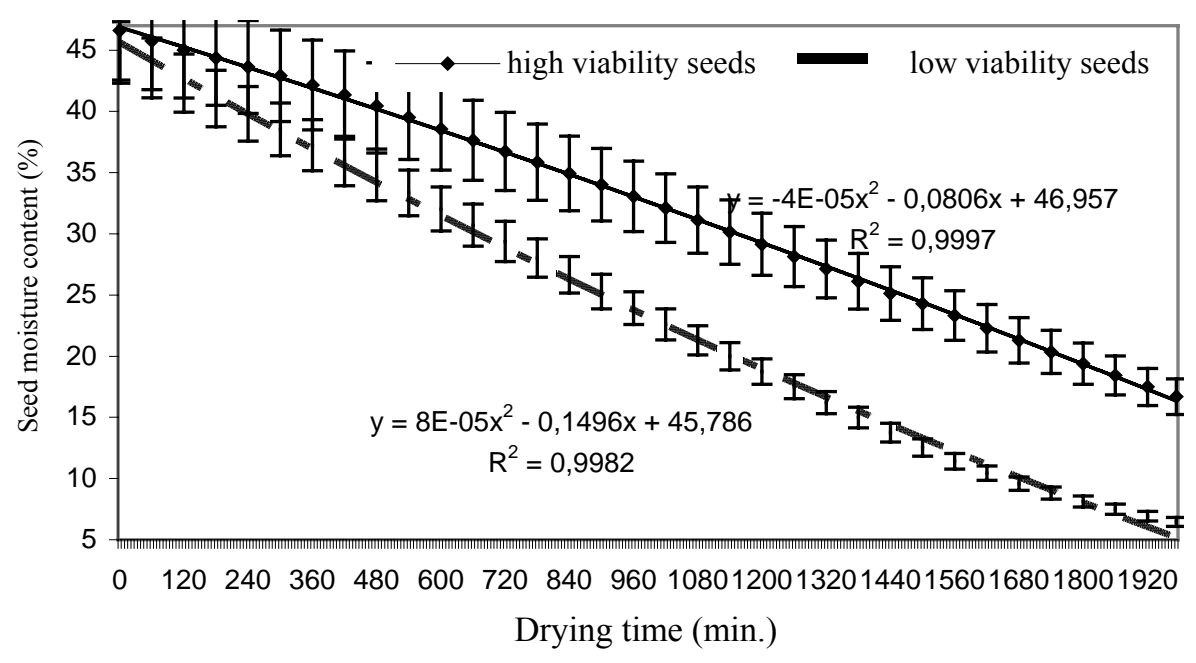

Fig. 3. Drying dynamics of 'Tina' common bean seeds

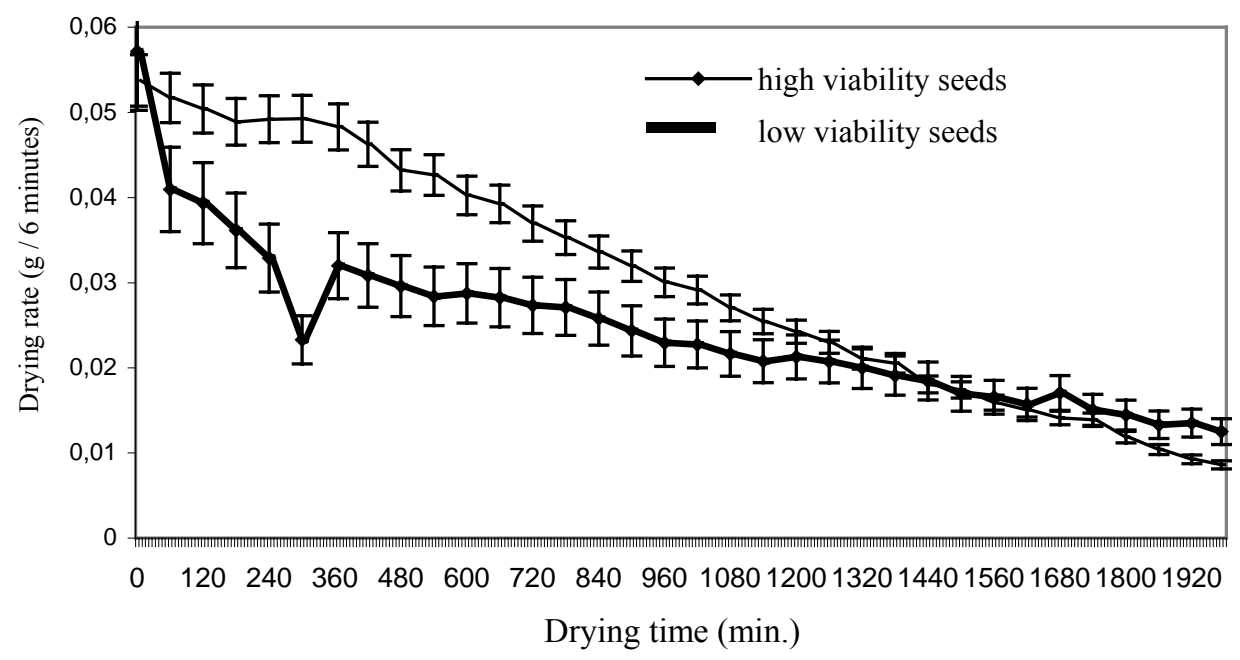

Fig. 4. Drying rate of 'Libra' common bean seeds 


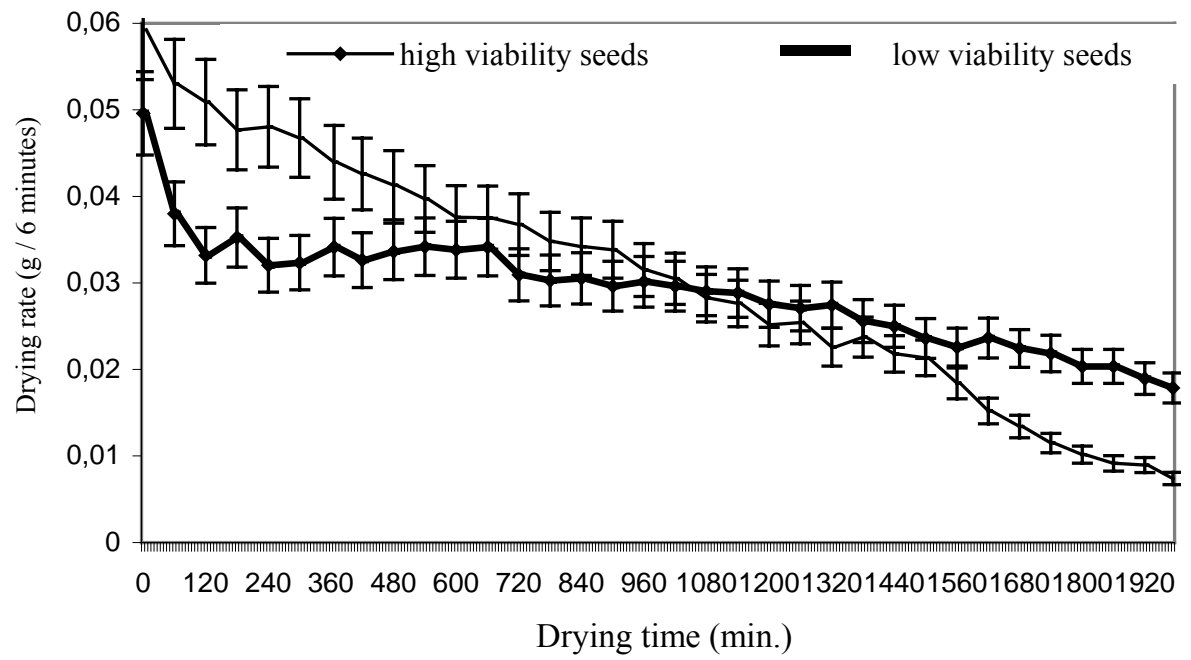

Fig. 5. Drying rate of 'Tina' common bean seeds

Out of the two tested characteristics, the drying rate seems to be more convenient for practical use. The used masses of 50 bean seeds were easily made equal, whereas adjusting their moisture content was more time consuming and therefore more expensive.

In the future, routine seed testing will be connected with developing quick and cheap methods to evaluate seed quality. The proposed method could possibly be one of them.

\section{REFERENCES}

Artola A., Carrillo-Castaneda G., 2004. A seed vigor test for Lotus corniculatus L. based on vacuum stress. Seed Sci. Technol. 32: 573-581.

ChODUlSKa L., POLANKA S., 2001. Wpływ uszkodzeń nasion fasoli szparagowej (Phaseolus vulgaris L.) na ich kiełkowanie w laboratorium i wschody w polu. Folia Hort.13/1a: 203-209.

FORNAL Ł., FILIPOWICZ A., 2007. Ocena jakości jęczmienia browarnego. www.eureqa.pl.

Freitas R.A., Dias D.C.F.S., Oliveira M.G.A., Dias L.A.S., JoSE I.C., 2006. Physiological and biochemical changes in naturally and artificially aged cotton seeds. Seed Sci. Technol. 34: 253-264. 
HoŁubowicz R., Wang X., SiUTAJ W., 2001. Use of tetrazolium (TTC), Germ's and greenhouse plant emergences methods for testing seed vigour of selected ornamental plant species. Acta Agrobot. 54: 5-17.

ISTA, 2004. Międzynarodowe Przepisy Oceny Nasion. Aneks do rozdz. 5: Oznaczanie zdolności kiełkowania, 5A: 49-59.

KWONG F.Y., SELlman R.L., VAN DER SCHOOR R., 2005. Flower seed cleaning and grading. In: Flower Seeds: Biology and Technology. McDonald M.B. and Kwong F.Y. (eds). CABI Publishing, UK: 225-247.

MCDonald M.B., 1998. Seed quality assessment. Seed Sci. Res. 8: 265-275.

Mirdad Z., Powell A.A., MAthews S., 2006. Prediction of germination in artificially aged seeds of Brassica spp. using the bulk conductivity test. Seed Sci. Technol. 34: 273-286.

MODI A.T., 2005. Assessment of pepper seed performance using desiccation sensitivity. Seed Sci. Technol. 33: 19-30.

Mussumeci F., Triglia A., Grasso F., Sordino A., SitKo D., 1994. Relation between Delayed Luminescence and Functional State in Soya Seeds. www.wsp.krakow.p1/biofiz.

STRONA J., 1977. Uszkodzenia nasion - przyczyny i zapobieganie. PWRiL, Warszawa: 1-213.

TARZALi M., LOHWASSER U., NiedZIElSKi M., BORNER A., 2005. Effects of different temperatures and atmospheres on seed and seedling traits in long-term storage experiment on rye (Secale cereale L.). Seed Sci. Technol. 33: 713-721.

TIGABU M., ODEN P.C., 2004. Rapid and non-destructive analysis of vigour of Pinus patula seeds using single seed near infrared transmittance spectra and multivariate analysis. Seed Sci. Technol. 32: 593-606.

ZALEWSKI K., GÓRECKI R., GÓRECKI M., WiTKOWSKI J., 1997. Metabolizm starych nasion, zmiany fizjologiczne w nasionach roślin strączkowych podczas przechowywania. Biul. IHAR 201: 199-210. 


\section{WPŁYW ŻYWOTNOŚCI NASION FASOLI ZWYKŁEJ (PHASEOLUS VULGARIS L.) NA DYNAMIKĘ ICH WYSYCHANIA}

Streszczenie: Nasiona fasoli zwykłej (Phaseolus vulgaris L.) odmian 'Tina' i 'Libra' o początkowej zdolności kiełkowania $98 \%$ poddano procesowi sztucznego starzenia $\mathrm{w}$ komorze termicznej $\mathrm{w}$ temperaturze $45^{\circ} \mathrm{C}$, w dwóch etapach po 72 godziny. Po tym zabiegu nasiona miały obniżoną żywotność. Zdolność kiełkowania nasion odmiany 'Libra' wynosiła $12 \%$, a odmiany 'Tina' $0 \%$. W uzyskanych w ten sposób próbkach nasion o zróżnicowanej żywotności wyznaczano dynamikę wysychania nasion oraz obliczano tempo wysychania nasion. Stwierdzono, że nasiona obu odmian, charakteryzujące się wysokim wigorem wyrażonym wyższą zdolnością kiełkowania, wysychały wolniej niż takie same nasiona o niskim wigorze. W przyszłości ocena szybkości wysychania nasion prawdopodobnie będzie mogła być wykorzystywana do oceny nasion o różnej żywotności. 